\title{
Ecocriticism of Sinandong Batolurlah Kau Sinangin Melayu Culture in Tanjungbalai, North Sumatra
}

\author{
Fitra Audina, Tedi Permadi, Nuny Sulistiany Idris \\ Indonesian Language Education, Graduate School \\ Universitas Pendidikan Indonesia, UPI \\ Bandung, Indonesia \\ fitraaudina@upi.edu, tedipermadi@upi.edu,nuny@upi.edu
}

\begin{abstract}
Sinandong Batolurlah Kau Sinangin is a product of oral tradition in Tanjungbalai which serves as the medium for transmitting cultural values like poems, mantra, and others. This oral tradition is sung with affection, love, heartache, sorrow, etc. Sinandong is rich in didactic values that have not been revealed much to the public. This study, therefore, aims to describe the depiction of nature or the environment presented in the text. Employing ecocriticism as the tool for analysis, it can describe the ideology of the text. The result reveals that Sinandong contains some values related to nature conservation in its lyrics. This implies that teachers, parents and community members need to play their roles in maintaining this local wisdom in their daily life.
\end{abstract}

Keywords: culture, ecocriticism, Sinandong Batolurlah Kau Sinangin

\section{INTRODUCTION}

Oral tradition is found in many cultures in Indonesia, one of them is a Melayu culture in Tanjungbalai, North Sumatra. Tanjungbalai is located on edge of the Asahan River, the longest river in North Sumatra province. The city that inherited Melayu customs has a variety of local wisdom in the form of art, for example, aloban condong, gubang, sinandong and others. These cultural heritages lost supporters because the youth of Tanjungbalai people are getting less interested in the culture. Sinandong, one of the heritages in forms of poem or mantra, is an oral tradition product that lives in Melayu culture as a media to convey the values of civilization through the performance of love, crying, grief, and others.

Sinandong is very rarely used today except in ceremonial events such as weddings, circumcisions, swinging children are no longer visible. According to Danandjaja (1984), the world of Indonesian education experiences a cultural inferiority complex due to colonized experience so that the emergence of the notion that foreign culture is more elegant than the culture of ancestors that looks stiff and worn or ancient. So that the young generation complains of foreign culture, especially at this time Korean, Japanese, Thai, European and other cultures. Then it eroded Indonesian culture which was considered "ancient" by Indonesian youths.

Researchers feel interested in analyzing Sinandong oral tradition because many convey very good messages to listen, one of which is a message to nature. In Tanjungbalai the main source of income for the community is the sea. Most people work as fishermen. So, this Sinandong tells the fishermen's anxiety about the sea. This shows that natural environmental sustainability.

The purpose of the ecocriticism approach to increase human awareness of nature by literature. Ecocriticism provides mechanisms to analyze cultural and literary texts directly or indirectly, related to ecological problems. The ecocriticism developed by Richard Kerridge as a broad cultural Ecocriticism (Garrard, 2004). If the ecocriticism developed a wider coverage than the ecocriticism of nature physically, then the object of study became wider, namely the culture widely. Culturally, the life of Tanjungbalai people can be explained with cultural elements, among others: (a) equipment and Equipment life, (b) Employment system, (c) Community systems, (d) language, (e) arts, (f) Knowledge system, and (g) Religious (Soekanto, 2007).

In the attempt to revitalize of oral tradition of Melayu culture in Tanjungbalai, namely Sinandong, researchers feel to need the attention this oral tradition, therefore researchers will raise this oral tradition as research material so as not to be eroded by time. Research has been conducted for Sinandong are:

1. Nilai-nilai pendidikan Islam dalam teks Sinandong Asahan pada masyarakat Melayu Tanjungbalai, Kecamatan Datuk Banda, by Siti Nuraisah Tanjung (2018),

2. Senandung bertelur kau sinangin pada masyarakat melayu di kota Tanjungbalai, by Arrini Shabrina Anshor (2015),

3. Kearifan lokal Sinandong tradisi lisan Melayu Tanjungbalai: Pendekatan antropologi sastra, by Syafriani Tio Sari (2017).

The differences this research with previous research is the study will be examined through an ecocritical study of a study of literary ecology The benefits of this research can remind us that human treatment of nature is so cruel that such criticism is conveyed through oral-literary.

\section{METHOD}

The title of this study is Ecocriticism of Sinandong Batolurlah Kau Sinangin Melayu Culture in Tanjungbalai, North Sumatra. It is a research descriptive analysis. Descriptive analysis is a qualitative study centered on empirical data, 
descriptive and refers to using an induction reasoning model (Miles \& Huberman, 1992).

The location of this research in Tanjungbalai city. Tanjungbalai city located on edge of the Asahan river, it is the longest river in North Sumatra province. The distance between the provincial capital of North Sumatra, Medan with Tanjungbalai about $186 \mathrm{~km}$ or about 5 hours away by car. The data in this study is Sinandong and Sinandong origin story. Data is obtained from the sinandong singer.

Researcher as the main instrument in this study to the process of observation. Techniques of the data collection used in this research are observations and field records. The theory of ecocriticism based on the writings of Glove (2003) as follows: (1) describes the depiction of nature or the environment into literature; (2) How the text outlines issues related to nature and the environment; and (3) How literary was analyzed using ecocriticism to describe ideology in the literature.

\section{FINDINGS AND DISCUSSION}

Sinandong was originally a special ritual sung by fishermen before going to the sea and after returning to the sea. Humming before leaving is a ritual to call the wind so that the fishermen can use the wind to go to the sea while humming after returning from the sea is a thanksgiving for the catch of the fish they get. But as the development of this ritual era has changed its function to become a means of entertainment at weddings, circumcisions, performances, and others, but today even at party events are not heard anymore, Sinandong has been forgotten.

Sinandong turned out to have an early story that would be briefly told as follows. One day, 3 fishermen were sailing by using a black boat sailing white calico cloth. Waves and storms like toying with their boat. At the time, they were sitting, one was sitting right on the stern of the ship so he was called Buritan, another was called Timba because he was in the middle of the ship, then finally given the name of Haluan because he's in front of the ship. Buritan sang the fate that had befallen them. Haluan seemed to have been swept away by his people who were accompanying the sung by Buritan. Timba continued to draw water into the boat because the wood of their boat was loose and caused the water to enter the boat. Because it's so hard he draws water makes a sound like a drum punch. It becomes a melodious combination of sound and music when hearing it.

TABLE I. Difference between original and wedding version

\begin{tabular}{|c|l|}
\hline Original version & \multicolumn{1}{|c|}{$\begin{array}{c}\text { Party or wedding version } \\
\text { (modern) }\end{array}$} \\
\hline Ooooiiiiii.... & $\begin{array}{l}\text { Didonglah di didong didonglah } \\
\text { Batolurlah kau } \\
\text { sinangin } \\
\text { Batolur sepanjang } \\
\text { pante }\end{array}$ \\
Barhombuslah kau & Didonglah kunun sayang \\
angin & Ooooiii \\
& Didonglah didong \\
& sayang \\
\hline
\end{tabular}

\begin{tabular}{|c|c|}
\hline 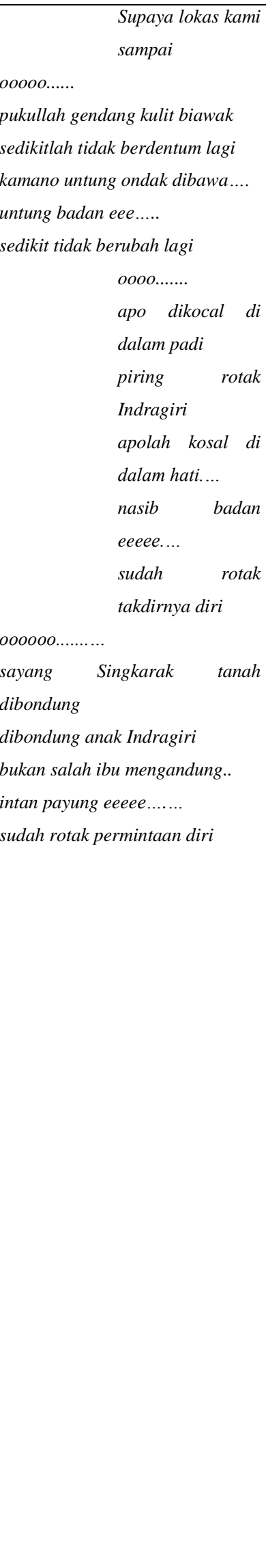 & 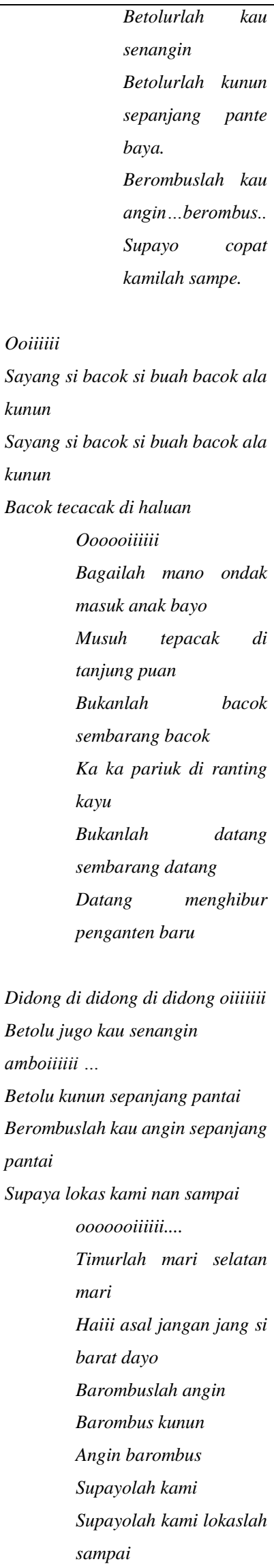 \\
\hline
\end{tabular}




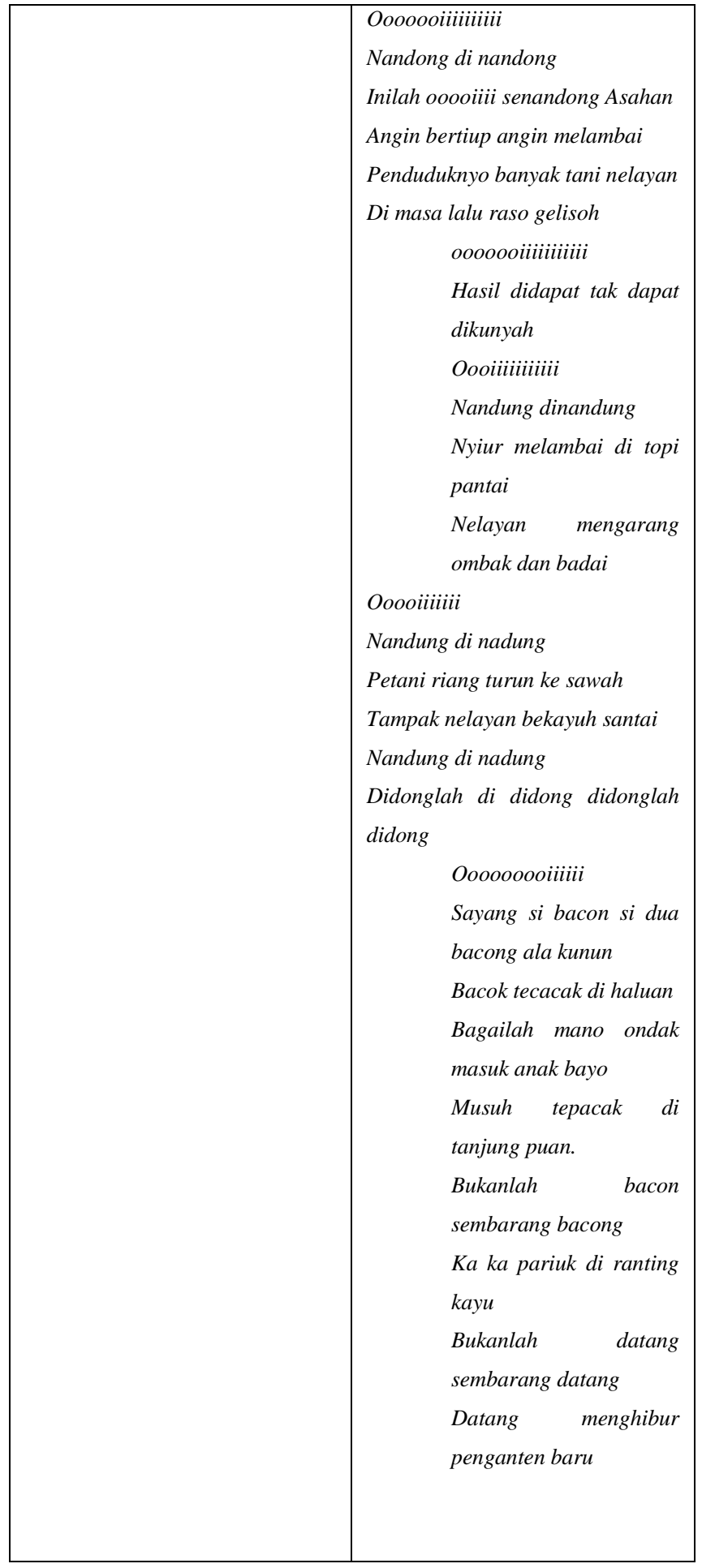

Table I shows the difference of the original version and the Sinandong version at the wedding is Sinandong which has not been sung at traditional events. this Sinandong is purely used as a ritual for the fishermen before going to the sea and after returning from the sea while Sinandong being sung at the party is added with messages for the bride. However, this Sinandong, although it has changed, is still classified as an oral tradition because its creator is unknown. But nowadays, Sinandong is known by the public that was sung at the wedding party.
A. Sinandong represent nature and outlines issues related to nature and the environment

Ooooiiiiii.....

Batolurlah kau sinangin

Batolur sepanjang pante

Barhombuslah kau angin

Supaya lokas kami sampai

The meaning of batolurlah kau sinangin, batolur sepanjang pante means that the poet asks for the coming of the wind to the shore, barhombuslah kau angin supayo lokas kami sampe means that the fishermen requested, the wind comes so earlier because he wants to go to the edge. At that time the boat used by fishermen didn't use engines but the sails and hoped the wind could push their boat. From this meaning, it can be seen that Sinandong represents nature as a physical setting or description object. Sinandong illustrates that the importance of the relationship or harmony between nature and humans. without description that humans can establish harmony between humans and nature, so humans tend to exploit the natural wealth and nature will be victims of cruelty from the nature of human dissatisfaction.

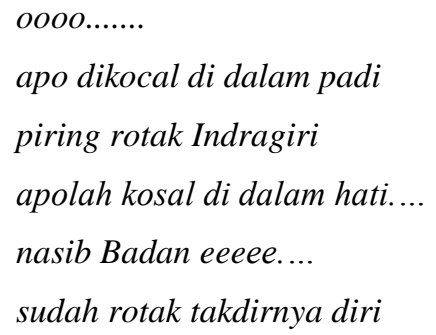

Apart from being a fisherman, tanjungbalai people also as a farmer, and because its, there is description of rice plant. Apo dikocal di dalam padi, pring rotak Indragiri. it means that what must be done again rice plant is not growing planted. If it is connected by the first text, they have surrendered themselves to destiny. This text actually has a story. It is said that the fishermen went out to sea and it turned out, during the trip their boats were hit by waves and storms before reaching the middle of the sea, but their supplies had run out until they decided to return after the storm go out. So, they go home without catches, because they don't get the catch, they widen the sails of the boat while throwing water from the boat. Feeling sad they sang a heartbreaking song. The meaning of the song is hopeless that the wind came so that the sails of the boat are pushed to the edge. The entire contents of the Sinandong text tell about the state of society at that time. When they go to sea, they don't get fish. And then when they plant, even rice plant doesn't grow. Sayang Singkarak tanah dibondung, dibondung anak 
Indragiri, bukan salah ibu mengandung. it means, this is the state of our birth land, it isn't wrong anyone but this is our fate.

The lyrics used are also related to plants and animals for example in lyrics

....pukullah gendang kulit biawak....

....apo dikocal di dalam padi....

...Angin bertiup angin melambai....

The text is translated to be

......beat the drum of lizard's skin....

.....what's done in a rice field....

.....Wind is blowing, wind is waving.....

There are lizard, rice plants, and wind, it's all about nature. The whole lyrics use words that come from plants and animals. Plants and animals that describe the state of society. Including poverty that hit the community at the time. Poverty is illustrated by the unfavorable condition of the sea namely the waves and storms while on the land of the farmers face crop failure.

Another story that is often told by the people of Tanjungbalai about Sinandong is a meeting between the fishermen as a singer of Sinandong with Princess Margolang, the son of King Margolang, the king who was enthroned at that time. When the fishermen sang Sinandong, the princess heard the song and felt sad. So, he sent Mak Inang, the closest slave to him. Mak Inang went to carry out the princess's orders. Everything that was seen by Mak Inang was told to the princess. Princess is very sad, she also went to meet her father. However, the princess was surprised to see her father and mother making out. Return the princess in disappointment and shut herself in her room and not come out again. The father felt uneasy because he did not know what caused the princess's illness. The father also asked the matter to the host Inang. After hearing the story of Inang, the king felt so shocked and angry that he ordered all his guards to win the fishermen.

After the fisherman was captured and taken to the kingdom, they were shocked. They feel they have done nothing wrong. The fishermen sang Sinandong again, hearing that Sinandong came out of the princess from her room. Princess told her father that she lied saying there were no difficult people, all the people lived happily. Hearing the words of his daughter he gave to land fishermen to where they live with their families. The fishermen feel very grateful to the king and princess. After the king died, the Putripun succeeded his father as the king of the area. The princess is very loved by all her people. News of Putripun was heard in another kingdom that there was a princess who was very beautiful and kind. A prince from another kingdom came with the intention of marrying a princess. The princess refuses the prince. The prince was angry and told all his guards to kill everyone in the princess palace. Princess was killed near the Patak River and disappeared in an instant.

Mak Inang remembered the message delivered by the princess that when she died go to the Patak River on the full moon then you would see me. So, on a full moon night, Mak Inang went to the river with all his people and also the men and women. How surprised everyone was to see the princess present from the bottom of the water and before long it disappeared again to the bottom of the water. This story is called the story of Sungai Ular Patak

Actually, telling with these supernatural stories, community leaders want to keep the river from being exploited by humans so that people do not dare to do things that damage nature because of fear of the supernatural power.

\section{B. Literary was analyzed using ecocritism to describe ideology in the literature}

The Malays realized that his entire life depended on the universe. Real nature is always related to the supernatural realm. The Malay people's lives were influenced by nature so that humans had to submit to the power of the universe. If you want to live safe and peaceful, then the Malay community must maintain the environment, and maintain the harmony of life between people with its environment and society with the world.

Visible from this lyric:

Cenggok- cenggok payong Malako

Payong boso rajo mudo...

Mak alang oi...

Jangan rusak nak jangan binaso,

Bogi kuntom bungo cempako

Nyiur melambai di topi pantai oooooooooiiiiiiiiiiii

Nelayan mengarang ombak dan badai

ooooooiiiiiiiii nandung di nadung.....

Petani riang turun ke sawah

ooooooooiiiiiiiiiiii Tampak nelayan

bekayuh santai

Oooooooooooiiiiiiiiii nandung di nadung......

For their environmental society is the beach, it is very important for them to keep the beach from being damaged and dirty so that the fish remain awake, if the marine ecosystem is damaged it will impact fish. While the livelihood of the community is sea. The profession of society is fishermen.

Angin bertiup angina melambai

Oooooooooooooiiiiiiiiii Penduduknyo banyak

tani nelayan oooooiiiiiiiiiii

Di masa lalu raso gelisoh.

Hasil didapat tak dapat dikunyah

Oooooooooiiiiiiiiiiiiiii nandung dinandung

The results of this study describe that:

1. Sinandong represents nature in each of its lyrics

2. Sinandong represents nature as a physical setting or description object. 
3. The value of environmental education is illustrated through the lyrics and narration of this Sinandong story.

\section{CONCLUSION}

Local wisdom in the sinandong of Malay community Tanjungbalai is hard work, education, health, conservation and cultural creativity, caring environment, courtesy, loyalty, harmony, commitment, and gratitude.

The oral tradition of Sinandong has lost its supporters because people have very rarely used this tradition. Therefore, researchers hope that people use this Sinandong on every event to avoid extinction. Researchers also hoped to make the Government's cultural conservation efforts one of the areas of the oral tradition of Sinandong.

This sinandong still can be examined in terms of structural and also character education. Therefore, researchers hope that this writing can be used as a source of reference for other researchers.

\section{REFERENCES}

Anshor, A. S. (2015). Senandung bertelur kau sinangin pada masyarakat melayu di kota Tanjungbalai (Studi terhadap bentuk musik, fungsi, dan makna) (Unpublished doctoral thesis). Universitas Negeri Medan.

Danandjaja, J. (1984). Folklor Indonesia: Ilmu gosip, dongeng, dan lain-lain. Jakarta: Grafiti Pers.

Garrard, G. (2004). Ecocriticism. USA and Canada: Routledge.

Glove, G. A. (2003). Practical ecocriticism, literature, biology, and the environment. London: University of Virginia Press.

Miles, M. B., \& Huberman, A. M. (1992) Qualitative data analysis (T. R. Rosidi, Trans.). Jakarta: UI-Press

Sari, S. T. (2017). Kearifan lokal Sinandong tradisi lisan Melayu Tanjungbalai: Pendekatan antropologi sastra (Unpublished bachelor's thesis). Universitas Sumatra Utara.

Tanjung, S. N. (2018). Nilai-nilai pendidikan Islam dalam teks Sinandong Asahan pada masyarakat Melayu Tanjungbalai, Kecamatan Datuk Banda (Unpublished bachelor's thesis). Universitas Sumatra Utara. 